\title{
THE LOGISTICS FOR EDWARD I'S ILL-FATED CAMPAIGN IN FLANDERS (1297-1298)
}

\author{
by Bryce and Mary (†) Lyon
}

Edward I ascended the throne of England on 23 November 1272, the day when Edmund, king of the East Angles (855 to 20 November 870) achieved his martyrdom. Consequently each regnal year of Edward began on 20 November and ended on 19 November the following year. It was in his twenty-fifth regnal year (20 November 1296 to 19 November 1297) that Edward made preparations for his campaign to be launched from the county of Flanders against Philip the Fair of France and that he, his household staff, and army were in Flanders during the autumn of 1297 and winter of 1298. The military strategy of Edward copied that of his grandfather John who had planned a two-front offensive against Philip Augustus, one from Gascony in southwestern France and the other from Flanders. John's strategic plan had ended in failure, with the defeat of his allied Low Country and German forces at Bouvines in 1214.

Despite his alliance with Count Guy de Dampierre of Flanders and pledge of military assistance against Philip the Fair, Edward was slow in fulfilling his promise because of English baronial resistance to foreign military service and exorbitant taxes and the time needed in assembling a force, ships for transportation, and supplies. Edward and his force transported by a total of 273 ships from Sandwich and Wynchelsea finally sailed on 24 August 1297, the destination being the Zwyn estuary. But it was too late to reverse previous Flemish defeats by Philip the Fair. Edward, therefore, arranged a truce with Philip the Fair on 9 October at St. Baafs Vijve that was extended into 1298. In January Philip and Edward parleyed at Tournai and agreed to a final peace treaty concluded at Montreuil-sur-Mer on 27 July 1298. Guy and Flanders had been abandoned by Edward and were at the mercy of Philip who planned to incorporate Flanders into his realm. Only the striking Flemish victory at Courtrai in 1302 preserved the independence of Flanders. With nothing accomplished, Edward and his force embarked at Sluis in the middle of March 


\section{BRYCE AND MARY (†) LYON}

and returned to Sandwich. Unencumbered with supplies taken to Flanders, a fleet of only 100 ships was required for the transportation back to England. ${ }^{1}$

The ill-conceived alliance between Edward and Guy de Dampierre with its unfortunate political consequences for Guy has received considerable scholarly attention by Belgian and French historians. Most British historians, however, have paid slight attention to Edward's campaign, treating it primarily as a major cause of the constitutional confrontation between Edward and a majority of his barons. In 1297 because of his heavy military commitments, Edward was compelled for the fourth consecutive year to demand a high tax on personal property. Most of the barons and numerous prelates opposed this tax and demonstrated in force. With Edward already enroute to Flanders, his son and chief officials summoned the barons, prelates, and knights from the shires to discuss a solution. An agreement was reached for a lighter tax in return for the royal confirmation of Magna Carta and the Charter of the Forest. Known as the Confirmation of the Charters, it stipulated in its most enduring clause that henceforth Edward would levy no tax without the consent of those taxed. This agreement was confirmed by Edward on 5 November at Ghent. ${ }^{2}$

1 Some of the earliest Belgian historians to discuss the Flemish campaign of Edward I were E. Varenbergh, Histoire des relations diplomatiques entre le comté de Flandre et l'Angleterre au moyen age, Brussels, 1874; Kervyn de Lettenhove, Histoire de Flandre, Bruges, 1853, Vol. I, and "Comptes de l'expédition d'Edouard Ier en Flandre", Bulletin de la Commission Royale d'Histoire, XIII, 1872, pp. 185-198. See also H. Pirenne, Histoire de Belgique, $5^{\text {th }}$ ed., Brussels, 1929, I, 365 ff.; Algemene Geschiedenis der Nederlanden, ed. H. Van Werveke et al., Antwerp, 1950, Vol. II; J. De Sturler, Les relations politiques et les échanges commerciaux entre le duché de Brabant et l'Angleterre au moyen âge, Paris, 1936, and 'Deux comptes 'enrolés' de Robert de Segre, receveur et agent payeur d'Edouard I ${ }^{\text {er }}$, roi d'Angleterre, aux PaysBas (1294-1296)," Bul. Com. Roy. Hist., CXXV, 1960, pp. 561-612. For some of the French historians see F. Funck-Brentano, "Documents pour servir à l'histoire des relations de la France avec l'Angleterre et l'Allemagne sous le règne de Philippe le Bel," Revue Historique, XXXIX, 1889, pp. 326-348, and Philippe le Bel en Flandre, Paris, 1897; J. Favier, Philippe le Bel, Paris, 1978. For a different view of Philip the Fair see J.R. Strayer, The Reign of Philip the Fair, Princeton, 1980. For other pertinent works see G. Barraclough, "Edward I and Adolf of Nassau," Cambridge Historical Journal, VI, 1940, pp. 225-262; F. Bock, "Englands Beziehungen zum Reich unter Adolf von Nassau," Mitteilungen des Osterreichischen Instituts für Geschichtsforschung, Erg.Band XII, 1932; and F. Trautz, Die Könige von England und das Reich, 1272-1377, Heidelberg, 1961. For a royal clerk's sketch of Edward I and Philip the Fair talking at Tournai which is depicted on the Lord Treasurer's Remembrancer, Memoranda Roll 69, membrane 54 in the Public Record Office (Document E.368/69 M54) see B. Lyon, "What Made a Medieval King Constitutional?" in Essays in Medieval History Presented to Bertie Wilkinson, Toronto, 1969, pp. 157-175.

2 One British historian who has not slighted Edward's Flemish campaign is M.C. Prestich whose studies are most valuable for the campaign and also for the constitutional crisis of 1297. Among them are War, Politics and Finance Under Edward I, Totowa, N.J., 1972, Documents Illustrating the Crisis of 1297-98 in England, in Camden Fourth Series of Royal Historical Society, London, 1980, Vol. 24, Edward I, Berkeley, 1988 (especially chap. 15, pp. 376-400), English Politics in the Thirteenth Century, London, 1990, and The Three Edwards: War and State in England, 12721377, New York, 1980. See also F.M. Powicke, The Thirteenth Century, 1216-1307, 2d. ed., Oxford, 1962. 


\section{THE LOGISTICS FOR EDWARD I'S ILL-FATED}

With this background let us now see what the wardrobe book for the twentyfifth regnal year of Edward tells us about his preparations for the campaign, the transportation across the North Sea, the payments to various fighters and sailors, the preparations for Edward's stay in Ghent, and the provisions for food and wine and their storage. The shear bulk of this record makes it almost certain that it will never be completely edited and published. Larger even than the wardrobe book of Edward III (12 July 1338 to 27 May 1340) edited some years ago, it comprises 152 parchment folios recto and verso measuring approximately 13 inches (.325 centimeters) in length and 8 inches (.160 centimeters) in width. It is drawn up in the typical chancery hand of the late thirteenth century and filled with numerous abbreviations for Latin words. All dates are in Roman numerals as are the wages, various expenses, and totals of such personnel as soldiers and sailors. ${ }^{3}$

This wardrobe book consists of fifteen categories of expenses, receipts, and accounts rendered by various officials: alms and oblations; necessary sundry expenses; expenses for food, provisions, wine, and their storage; fiefs and wages for household knights; wages of bannerets and knights; wages of crossbowmen, men-at-arms, and squires; wages of foot soldiers, archers, and laborers; wages of sailors and expenses for the fleet; expenses for messengers; wages and expenses for falconers and hunters; grants of dona; money for the clothes of members of the king's household; jewels bought, received, and given by the wardrobe; jewels received by the wardrobe from divers individuals; and purchases by the great wardrobe. The following is an example of one of the titles for these categories: "Titulus de necessariis diversis emptis et provisis pro rege Edwardo filio regis Henrici liberatis suis vallettis de hospicio suo et aliis et de equis emptis pro ipso rege, diversis officiis hospicii sui versus partes Flandrie et pro ducissa Brabancie et comitissa Hollandie filiabus regis contra passagium earum versus partes proprias una cum expensis nunciorum sollempnium missorum usque Cameracum et alibi in nuncium regis predicti et una cum vadiis quorundam qui non sunt ad vadia dicti regis in

3 The wardrobe book was formerly in the British Museum and listed as B.M. Add. MS, 7965. Since the reorganization of the British Museum and the Library this record is listed as B.L. Add. MS, 7965. Subsequently this record will be cited as Ward. Bk. Ed. I. For the functions of the wardrobe and its records see T.F. Tout, Chapters in the Administrative History of Mediaeval England, Manchester, 1920-1933, Vols. I-VI; E.B. Fryde, The Book of Prests of the King's Wardrobe for 1294-5, Oxford, 1962; Charles Johnson, "The System of Account in the Wardrobe of Edward I," Transactions of the Royal Historical Society, VI, 1923, pp. 50-72; J.H. Johnson, 'The King's Wardrobe and Household," in J.F. Willard and W.A. Morris, eds., The English Government at Work, 1327-1336, Cambridge, Mass., I, pp. 250-299; M.C. Prestwich, "Exchequer and Wardrobe in the Later Years of Edward I," Bulletin of the Institute for Historical Research, XLVI, 1973, 1-10; and the Introduction by B. Lyon in B. and Mary Lyon, eds., The Wardrobe Book of William de Norwell (12 July 1338 to 27 May 1340), Brussels, 1983. 


\section{BRYCE AND MARY (†) LYON}

rotulo marescallie sue et cum calciaturis diversorum vallettorum de officiis et garcionis de hospicio suo a festo sancti Edmundi regis et martyris et cetera ut supra titulo de elemosina."4

With no hope of transcribing the mountains of information in this wardrobe book, we have limited ourselves in what follows to the entries most pertinent to Flanders. The following are but a few of the entries pertaining to materials needed to outfit the ships for transporting hundreds of horses to Flanders. Stalls and gangways for the horses had to be constructed. The items procured and their costs are listed in the Necessaria under the sub-heading of "Necessaria provisa pro flota navium apud Wynchelse congregata contra passagium regis versus Flandriam anno regni sui $x x v t^{\circ} . " 5$ Nicholas Alard of Winchelsea received $22 \mathrm{lb}$. on 22 August 1296 for procuring 2,750 boards 10 feet in length "pro navibus reparandis ad equos pro passagio regis versus Flandriam." John Fish received $13 \mathrm{lb} .6 \mathrm{~s} .11 \mathrm{~d}$. for 100 boards 12 feet in length and 625 boards 10 and 8 feet in lenght. For 300 boards, some a half foot wide and some three-quarters of a foot wide, and varying in length from 6 tot 7 feet, he received $10 \mathrm{lb} .6 \mathrm{~s} .3 \mathrm{~d}$.

Richard Finour received $8 \mathrm{lb}$. 2 s. for 675 boards ten feet in length at the prices of $24 \mathrm{~s}$. per one hundred boards. Eight master carpenters constructed 8 gangways to embark the king's destriers and palfreys. Each gangway cost $3 \mathrm{~s}$. Lawrence le Cupper, who was assigned to provide nails for the gangways, acquired 22,000 nails for $64 \mathrm{~s}, 14,140$ nails for $54 \mathrm{~s}$. $3 \mathrm{~d}$., and 2,000 nails for $4 \mathrm{~s}$. For transporting these nails from various places to Winchelsea, he received 6 lb. $16 \mathrm{~s}$. $3 \mathrm{~d}$. He even provided a table for the counting of money and some canvas for the harnesses of the horses. ${ }^{6}$

\section{Ward. Bk. Ed. I, $\mathrm{f}^{\circ} 11 \mathrm{v}$.}

5 Ibid., $\mathrm{f}^{\circ} 36 \mathrm{v}$.

$6 \quad$ Ibid. "Laurencio le cuppere de Wynchelse assignato ad claves providendum pro navium bordandis ad equos pro 22,000 clavorum emptorum per pactam precio mille, $2 s$. 11d. minus $2 d$. in toto $64 s$. et pro 14,140 clavis emptis per loca precio mille, 3s. 10d., 54s. 3d. Et pro 2,000 clavis emptis precio mille $43 / 4 s, 8 s .11 / 2 d$. Et pro cariagio eorundem clavorum de diversis locis usque Winchelse una cum conductione equorum et expensarum eiusdem Laurencii per 6 vices eundo per pactam pro eisdem clavis providendis 10s. Summa $6 \mathrm{lb}$. 16s. 3d." For English medieval ships, fleets, and their personnel see T.J. Runyan, "The Organization of Royal Fleets in Medieval England," in Runyan, ed., Ships, Seafaring, and Society: Essays in Maritime History, Detroit, 1987, and B. Lyon, "The Infrastructure and Purpose of an English Medieval Fleet," Handelingen der Maatschappij voor Geschiedenis en Oudheidkunde te Gent, LI, 1997, pp. 61-76. 


\section{THE LOGISTICS FOR EDWARD I'S ILL-FATED}

Sandwiched in among these entries is a variety of miscellaneous information associated with the king's crossing. Under the notation Elemosina regis is this entry: "Fratribus de Monte Carmeli de Sandwico divina celebrantibus per tres dies mense Septembris anno presenti in honore sancte Trinitatis, sancte Crucis et Spiriti Sancti pro passagio flote navium ibidem congregata versus Flandriam ad pitanciam nomine elemosine regis, $7 \mathrm{~s} .6 \mathrm{~d} . " 7$ Philip de Everdon, a royal clerk, was dispatched in great haste from Winchelsea to London to procure the small seal which had been left behind. In August 1296 the mayor of Sandwich was remunerated with 40s. 1d. to repay him for arranging the passage of "Copikayen nuncii comitis Flandrie de Sandwico usque Le Swyne." 8 . At the end of this section the total expenses are given as $40 \mathrm{lb}$. $18 \mathrm{~s}$. $6 \mathrm{~d}$. And on the last folio pertaining to all of the necessaria is this entry: "Summa totalis necessariorum per se, 6,684 lb. 13s. 5d. probatur."9

The wardrobe book documents Edward's need of money while in Flanders because the wardrobe was responsible for paying his immediate expenses as well as the subsidies and fiefs-rentes granted not only to Guy and Duke John II of Brabant but also to other Low Country and German allies. ${ }^{10}$ Much of the money was supplied by the exchequer and had to be transported to Flanders. The logistics were awesome. Barrels for the silver pennies had to be acquired and made secure by coopers. Also needed were carts and horses for overland transportation, ships and barges, guards, and secure storage sites. The royal jewels and silver and gold plate also accompanied Edward, some of which was pawned, some exchanged in return for sums of money received from merchants and bankers, and some given for special services.

An account by the king's clerk William de Dogmeresfelde in the autumn of 1297 reveals some of the logistics involved. He paid 50s. for 2 carts to transport the royal jewels and plate in their coffers from Bruges to Brussels and thence to Malines. For loading, unloading, and guarding these 3 coffers for 3 nights he paid 53s. From Malines the jewels and plate were taken to Louvain, then to Antwerp, and finally to Ghent. For storing the jewels for

7 Ward. Bk. Ed. I, f ${ }^{\circ} 37 \mathrm{r}$.

8 Ibid., "Eidem [Everdon] misso cum festinacione post passagium regis de Winchelse usque Londoniam pro minori sigillo cancellarii regis querendo et redeunti." Philip Everdon had been cofferer of the wardrobe from 1290 to 1295 (Tout, Administrative History, VI, 30). Entry on Copikayen on same folio.

$9 \quad$ Ibid., $\mathrm{f}^{\circ} 38 \mathrm{r}$.

10 See especially B. Lyon, "The fief-rente in the Low Countries: An Evaluation," Rev. Bel. de Phil. et d'Hist., XXXII, 1954, 422-465, "Un compte de l'échiquier relatif aux relations d'Edouard I'er d'Angleterre avec le duc Jean II de Brabant," Bul. Com. Roy. Hist., CXX, 1955, pp. 67-93, and From Fief to Indenture: The Transition from Feudal to Non-Feudal Contract in Western Europe, Cambridge, Mass., 1957. 


\section{BRYCE AND MARY ( $\dagger)$ LYON}

12 days in a house in Malines the cost was 100s. in money of petits tournois which in English sterling was 22s. 10d. Many such payments were in petits tournois whicht indicates that English money had to be changed, certainly a source of revenue to local moneychangers. ${ }^{11}$

The trusted clerk Robert de Segre had to secure 36 barrels for money sent from Westminster to Sandwich and on to Flanders which was a payment to the count of Flanders "iuxta convencionem inter regem Anglie et ipsum comitem." The cost for transporting and guarding these barrels was $10 \mathrm{lb} .4 \mathrm{~s} .6 \mathrm{~d} .{ }^{12}$ Roger de Bray, sub-usher of the king's household, had purchased the 36 barrels, noted as necessary to carry $18,000 \mathrm{lb}$. to Flanders, as well as nails for the coopers hired to make them secure. The cost was 30s. $31 / 2 \mathrm{~d}$. Another clerk Henry de Monte Pessulano was responsible for the transport of 43 barrels of money "usque Flandriam pro comitibus Flandrie et de Baar." Henry's expenses for the land and sea transportation of these barrels on a ship called La Bayard from Yarmouth and for the transport and guarding of them along with some coffers of jewels and documents from the "portum de Swyne usque Brugge," were 53s. 3d. ${ }^{13}$

Some entries in the wardrobe book reveal what must have been frequent transactions to obtain relatively small amounts of money for Edward's immediate use. One such transaction occupies a large amount of space in the wardrobe book and the accounting demonstrates how thorough and scrupulous were the wardrobe staff. Most of the pertinent entries for this transaction are in the section that accounts for the king's jewels and plate. Under the heading of "Adhuc jocalia empta anno presenti" the first entry in the left margin is the following: "Ciphus argenti deauratus, ponderis 34s. 6d., precii 40s." Across from this entry in a right column is this notation: "Invadiatur per Hugelinum de Vikio per preceptum regis simul cum aliis jocalibus regis Albisso de Fisanti

11 Ward. Bk. Ed. I, $f^{\circ} 17 r$. In addition Dogmeresfelde was remunerated for the expenses of storing the king's jewels and wine in a house at Antwerp as well as for the transport from Winchelsea to Flanders of wine, ale, and water on 4 ships. He was reimbursed "pro gentaculis clericonum scribentium bullas."

12 Ibid., $\mathrm{f}^{\circ} 17 \mathrm{v}$. Robert de Segre was one of the busiest of Edward's clerks. He appears frequently in the wardrobe book serving in a variety of capacities. For his various services see De Sturler, Bul. Com. Roy. Hist., CXXV, pp. 561-612; Lyon, Bul. Com. Roy. Hist., CXX, pp. 67-93. As an agent for John II of Brabant, John, lord of Cuyk, collected a number of payments for a subsidy of $40,000 \mathrm{lb}$. in petits tournois noirs paid by Robert de Segre and other clerks in the years 1296-1298 at Antwerp. In 1294 Robert de Segre was entrusted to deliver subsidies totalling $25,000 \mathrm{lb}$. to certain Low Country lords. The involved 17 ships with 756 sailors to transport the money across the North Sea (Prestwich, War, Politics and Finance, p. 173). For more on Robert de Segre see Prestwich, Documents, Nos. 4, 206.

13 Ibid., fo $17 \mathrm{v}, \mathrm{f}^{\circ} 22 \mathrm{v}$. 


\section{THE LOGISTICS FOR EDWARD I'S ILL-FATED}

Lumbardo apud Andwerpiam pro $300 \mathrm{lb}$. sicut patet in recepta denariorum anni presentis." 14 Hugelino de Vikio was a trusted clerk of Edward who in other entries appears as a prominent member of the household entitled to money for his clothes and receiving payments for wages and expenses involved in a number of missions, one of them from London to Bruges and then to the king of Germany. ${ }^{15}$ This entry indicates that Hugelino took a small decorated silver cup from the wardrobe and gave it to the Lombard Albisso de Fisanti in part payment for $300 \mathrm{lb}$. given to Edward. Thirty-two more entries show Hugelino transferring to Albisso 28 small silver cups, 9 decorated silver cups, 14 silver pitchers with covers, 6 silver basins, 4 cups with covers and decorated at the base, 1 enamelled silver cup, 1 silver pitcher, 1 silver cup without a cover and decorated at the base, 2 large dishes for serving entrements, and a belt decorated with pearls. In an attempt to ascertain the commission or interest Albisso received for the $300 \mathrm{lb}$., we added all the weights given in terms of money of the various plate. The result was a total of $334 \mathrm{lb} .15 \mathrm{~s} .71 / 2 \mathrm{~d} .{ }^{16}$ This means that Albisso obtained a commission of about $11 \%$ for the $300 \mathrm{lb}$. But then to recover the $300 \mathrm{lb}$. plus the additional $34 \mathrm{lb}$. he had to sell all the plate for this amount. Perhaps he was a shrewd entrepreneur who sold what he had for an even greater amount.

To provide for Edward's household and force in Flanders huge amounts of food and supplies had to be procured from many counties of England and transported to Flanders where most was eventually stored at Ghent. Various officials were involved such as sheriffs of the counties, bailiffs and mayors of towns and ports, personnel of ships, tentmakers, carters, and royal officials, especially those of the wardrobe and household. The entries most frequently refer to all sorts of grain, flour, fish, wine, ale, hay for horses, and a variety of war materiel such as arrows, bolts, and helmets. Under Necessaria appear dozens of entries pertaining to these supplies. For example, under the notation of "Compotus Walteri le Blunt de blado et farrina receptis apud Bireflet in Flandriam" is an account of his procurements and expenses: "Walterus le Blunt missus per senescallum hospicii regis de Gandavo usque Bireflet in Flandria ad bladum et aliud instaurum regis proveniens usque ibidem recipi-

$14 \quad$ Ibid., $\mathrm{f}^{\circ} 133 \mathrm{v}$.

$15 \quad$ lbid., $\mathrm{f}^{\circ} 23 \mathrm{r}, \mathrm{f}^{\circ} 125 \mathrm{r}, \mathrm{f}^{\circ} 129 \mathrm{v}$.

16 These transactions are recorded on folios 133v-146r. The Lombard Albisso de Fisanti was a minor moneylender to Edward. More of his loans are described by E. B. Fryde, "Financial Resources of Edward I in the Netherlands, 1294-98: Main Problems and Some Comparisons with Edward III in 1337-40," Rev. Bel. de Phil. et d'Hist., XL, 1962, pp. 1168-1187. Fryde also provides more details on Robert de Segre. See Prestwich, Documents, p. 35 and No. 206 for other minor loans by other Lombards and merchants from Asti. See also R.H. Bowers, "From Rolls to Riches: King's Clerks and Moneylending in Thirteenth Century England," Speculum, LVIII, 1983. 


\section{BRYCE AND MARY $(\dagger)$ LYON}

endum reddit compotum de" 31 tuns of wheat flour, 472 quarters (a quarter is a dry measure equal to 8 bushels) of wheat, and 80 quarters of barley received from 2 sheriffs of London on 3 ships. In addition he received 70 quarters of oat flour and another 19 quarters of the same flour from another sheriff. Having received the grains and flour at Biervliet situated on the Honte, the western arm of the Scheldt River, Blunt then accounted for his disbursements of the grain and flour to functionaries of the household such as the baker, the poulterer, and clerks of the wardrobe. He even accounted for $161 / 2$ quarters of oat flour that had rotted on a ship during a storm at sea. Although Sluis received most of Edward's supplies, numerous entries indicate that Biervliet also received and stored considerable supplies. ${ }^{17}$

Under the notation of "Adhuc compotus Roberti de Segre de stauro recepto in Flandria et Brebancia" Robert de Segre, the busy clerk of the wardrobe, rendered account of 135 tuns of wheat flour, 5,773 quarters of wheat, $4981 / 2$ quarters of beans and peas, 194 quarters and $71 / 2$ bushels of barley, 3,943 quarters and $31 / 2$ bushels of oats, 521 tuns and 6 pipes of Rhenish wine, 42 tuns of ale, 51 3/4 cow carcasses, 3,677 hams, 10 vats of wine, 4,800 1/2 platfish, 1,300 eels, and 20,300 bales of hay. In a previous account Robert de Segre noted that all these supplies were worth $3,619 \mathrm{lb}$. $5 \mathrm{~s} .101 / 2 \mathrm{~d} .{ }^{18}$

At Ghent Edward and most of his household apparently lived in a house within the walls. Under the notation "Factura unius camini pro rege apud Gaunt" one learns that Thomas and Robert, two valets of the king's chamber, expended 48s. 3d. for materials, carpenters, and masons "pro uno novo camino faciendo in camera regis apud Gandavum." Among the materials for the chimney were timbers, nails, and iron bars. The account states that the money was paid in sesterces. ${ }^{19}$ When later the people of Ghent realized that Edward was deserting them, a number of serious skirmishes broke out between the English and Gantois. In February 1298 a plot was hatched to capture Edward and hand him over to the French. On an appointed morning the gates were closed so that the English force outside the walls could not assist Edward. There were numerous English casualties until the English troops burned down the gates and rescued Edward and his entourage. Many Flemish were killed and there was rampant plundering. 20

17 Ward. Bk. Ed. I, $\mathrm{f}^{\circ} 29 \mathrm{r}$. See also $\mathrm{f}^{\circ} 45 \mathrm{v}$. In an account by Peter of Chichester "receptori stauri regis apud Gandavum" are detailed the expenses for transporting, guarding, and storing various grains, flour, and wine at Biervliet, Antwerp, Ghent, Audenarde, and Aardenburg. The grains and flour were finally transferred to Walter de Waldeshef, the king's baker, at Ghent.

$18 \quad$ Ibid., $\mathrm{f}^{\circ} 44 \mathrm{r}$ and $44 \mathrm{v}$.

19 Ibid., $\mathrm{f}^{\circ} 23 \mathrm{v}$.

20 These confrontations are noted in the Annales Gandenses. For the Latin text and an English translation see Hilda Johnstone, trans., Annales Gandenses, New York, 1951. See also Prestwich, Edward I, pp. 394-395. For other such conflicts at Damme and Aardenburg see Prestwich, Documents, No. 149. 


\section{THE LOGISTICS FOR EDWARD I'S ILL-FATED}

Numerous are the references to projects "extra villam de Gandavo," of which the most ambitious was the construction of a fosse that appears to have been a defensive ditch or moat for a fortified site quartering Edward's force. We learn about this fosse from one of the most detailed and extensive accounts in the wardrobe book which, unfortunately, only locates it outside Ghent's walls. Although written and archaeological evidence on this fosse is slim, what evidence we have suggests that the fosse was located between St. Peter's abbey and the site of the present railway station, an area that in the thirteenth century was mostly unsettled because it consisted of marshland. The best clue to the fosse's locaton is in the fourth book of the Spiegel Historiael (1248-1316) by Lodewijk Van Velthem in verses under the rubric "Hoe die coninc Edeward van Ingelant in Vlaendren quam." On line 116 appear the words "In SentePetersdorp" describing the location of Edward's force outside the walls of Ghent. $^{21}$

The details on the construction of the fosse are under the heading "Compotus Ricardi de Wardington de operatione fossati extra Gandavum." 22 Richard de Wardington, the king's clerk, was deputized to pay wages "operariorum operantium in fossato extra villam de Gandavo solvenda quod rex fieri precepit ad sumptus suos in primo adventu suo ibidem."

Edward and his force had sailed from England on 24 August 1297, disembarked at Sluis, and then proceeded to Bruges where Edward met Count Guy. In early September they moved to Ghent where Edward established his base of operations. The fosse to be constructed had to be extensive enough to pro-

$21 \quad$ H. Vander Linden, W. De Vreese, and P. De Keyser, eds., Lodewijk Van Velthem's Voortzetting van den Spiegel Historiael (1248-1316), Brussels, 1931, pp. 228-240. The Annales Gandenses also situates the English force outside Ghent. For the reference to the Spiegel Historiael I am indebted to Dr. Marc Boone who also discussed the location of the fosse with Marie Christine Laleman, Ghent's archaeologist. She noted that a section of a wall dated roughly in the second half of the thirteenth century was found in the Saint Peter's area and that it had no connection with the thirteenth-century walls of Ghent.

22 Ward. Bk. Ed. I, $f^{\circ} 85 \mathrm{v}$. 


\section{BRYCE AND MARY (†) LYON}

tect a force estimated at some 895 cavalry and some 7,000 foot soldiers and archers. $^{23}$

The work began on 12 September and continued without interruption through 1 October. The Flemish did all the labor under the direction of master Gerard Merlebek. On 12 September Gerard and 24 workers began the operations, Gerard receiving $6 \mathrm{~d}$. daily and the workers $2 \mathrm{~d}$. On 13 September Gerard was joined by another master, Bartholomew of Ghent, and they supervised 99 workers. Gerard received 6d. daily and Bartholomew, 4d.; and the workers, 2d. On 14 September Gerard was assisted by 3 valets at 4 d. daily and supervised 199 workers. On one day 199 fossatori (literally trenchers or diggers) received wages of $2 s$. And so the work continued except on Sundays. Soon 4 masters were supervising more than 225 workers daily. On 19 September there were 260 workers plus 40 "puerorum portantium hottas" who only received 1 d. daily. On 20 September 360 workers were employed and on 21 September, 400. From then on until 1 October an average of 250 to 300 workers were employed. This, the first of 3 accounts rendered by Richard, totalled $29 \mathrm{lb} .61 / 2 \mathrm{~d} .{ }^{24}$

23 The best study on the size of Edward's force is by N.B. Lewis, "The English Forces in Flanders, August-November 1297", in Studies in Medieval History Presented to F. M. Powicke, Oxford, 1948, p. 313 ff. See also Prestwich, War, Politics and Finance, p. 52. When Edward and his force arrived at the Zwyn estuary a fight broke out between the sailors of Yarmouth and those of the Cinq Ports. During the struggle some thirty ships were lost. Most of the equipment of the wardrobe was on La Bayard of Yarmouth which was luckily saved when a man called Philip de Hales cut the mooring rope enabling La Bayard to drift free from danger. This incident is referred to in the wardrobe book on $\mathrm{f}^{\circ}$ 57r.: "Philippo de Hales transfretanti versus partes Flandrie in comitiva regis in nave que vocatur La Bayard de Jernemutha que assignabatur pro garderoba regis de dono eiusdem regis quia morabatur super custodem thesaurarii et hernesii eiusdem garderobe tempore contumelie suborte inter nautas Quinque Portium et Jernemutham apud la Swyne mense Augusti et salvavit eidem hernesio et thesaurario. $6 s .8 d . "$ It is also noted that John Alain, master of La Bayard "in qua thesaurarius et ceteri clerici garderobe regis una cum tota eadem garderoba transfretabant de Wynchelse usque Flandriam de dono ipsius regis nomine precii unius cabli cissi in mari pro salvatione eiusdem garderobe per manus proprias apud Gandavum, 33s 3d." For this conflict see F. W. Brooks, "The Cinq Ports Feud with Yarmouth," Mariner's Mirror, XIX, 1933.

24 Ward. Bk. Ed. I, f ${ }^{\circ} 85 \mathrm{v}$. On 4 December 1297 Edward ordered 50 miners from the Forest of Dean in England to assist the Flemish workers. Why these miners should have been ordered to Ghent almost two months after a truce had been concluded between Edward and Philip the Fair remains a mystery. It would appear that the Flemish workers had completed their task on 1 October. But see Prestwich, Documents, No. 182: "Nous vous mandoms fermement enioignantz qe de la forest de Dene nous faciez venir le plus en haste qe vous porrez cinquante bons mineurs." The English force deceived the larger French force into believing it was a formidable one by periodically sending foot soldiers carrying cavalry banners outside the fosse. See Lewis, in Studies Presented to Powicke, p. 315. 


\section{THE LOGISTICS FOR EDWARD I'S ILL-FATED}

A second account of Richard concerned the wages of the 4 masters and the fossatori who most certainly also did masonry work because they were assisted by many pueri carrying hod. On 27 September the 4 masters supervised 300 fossatori and 90 pueri. The masters received the usual wages; the fossatori, 2d.; and the pueri, $11 / 4 \mathrm{~d}$. Although more of this work continued on 28 and 30 September and on 1 October, fewer fossatori were employed. The final item in the account was for "signis plumbeis emptis per eundem ad liberandum operatoribus predictis ut per hec satisfacione posset eisdem." The cost for these lead tokens or signs was $21 / 2 \mathrm{~d} .^{25}$

The third account of Richard dealt with carpentarii. The carpenters, supervised by the master carpenter Gerard of Ghent, devoted themselves to constructing a brestachiam, that is, a wooden fortification of planks, often placed on the top of a wall for more protection. Gerard received $6 \mathrm{~d}$. daily and the carpenters, 4d. Twenty-one carpenters labored on 16 September, 36 on 17 September, and 34 on 18 September. The workforce then declined to 4 carpenters on 19 September, 5 on 20 and 21 September, 3 on 23, 24, and 25 September, 4 on 26, 27, and 28 September, and 3 on 30 September. The wages for this work totalled $45 \mathrm{~s} .2 \mathrm{~d} .26$

What the account leaves unsaid about this massive operation are the costs for the materials and the close liaison between Richard de Wardington and the various officials of Count Guy who quickly collected the workforce of masters, workers, fossatori, carpenters, and hod carriers. Such close rapport could only have occurred at the outset of Edward's stay at Ghent. In the winter of 1298 relations had so soured between Edward and the Gantois that armed skirmishes were normal and most of the Gantois were delighted when Edward departed from Sluis in the middle of March.

These three accounts and others show that Edward's campaign not only brought large subsidies and fiefs-rentes to Guy, John II of Brabant, and other Low Country and Rhenish lords but also benefits to those much lower in the social echelon. Despite the amounts of supplies brought from England more had to be procured in Flanders and Brabant. ${ }^{27}$ Edward's stay of some six months in Flanders must have briefly strengthened the Ghent enconomy ailing from the conflict between Guy and Philip the Fair.

Even religious orders and churches profited from Edward's alms and oblations which his almoner distributed soon after his arrival in Flanders. On 28 August 1297 oblations of $7 \mathrm{~s}$. were given "ad altare in capella sua apud La

25 Ward. Bk. Ed. I, fo 86r.

26 Ibid., fo 86r. For a transcription of these 3 accounts see the Appendix.

27 Ibid, $\mathrm{f}^{\circ} 10 \mathrm{r}$. 
Cluse." On 29 September oblations of 7s. were given "ad reliquias super altare in ecclesia beate Marie de Ardeburgh" and 7s. "ad imaginem beate Marie in eadem ecclesia." In Bruges the religious orders of the Premonstratensians, Franciscans, and Augustinians received various amounts "pro patura trium dierum." Oblations of 7s. were given "ad magnum altare in ecclesia sancti Basilici de Bruges in qua est sanguis Ihesu Christi." When in Ghent Edward regularly gave money for the food of three days to the Premonstratensians, Franciscans, Augustinians, Carmelites, and the brothers de Sacco. ${ }^{28}$

This wardrobe book primarily records Edward's preparations for his Flemish campaign and his first three months in Flanders, the period when both Edward and Guy de Dampierre had hopes of ousting Philip the Fair from Flanders and reversing Edward's embarrassing setback in Gascony. But their hopes were soon dashed and already in October Edward concluded his truce with Philip the Fair that was extended and ultimately became a peace later in 1298. For the last three months of Edward's stay in Flanders, one must consult other records. Of value in this wardrobe book is the information provided on how a medieval government prepared for war overseas, what was involved in mobilizing a force, transporting it, and maintaining it in another land. It portrays a staff of royal officials and their subordinates who maximized the operations for war with the limited economic, technological, communication, and transport services at their disposal in the late thirteenth century. Above all, it demonstrates that Edward's officials were very cognizant of what was being expended. Daily they knew what was paid for supplies, transportation, alms and oblations, gifts, messengers, clothes, purchases of horses, lumber, and even nails. They knew that yearly they were supposed to account for the wardrobe's receipts and expenditures to the exchequer. Records such as the wardrobe books give a picture of a medieval campaign that one seldom derives from chronicles which usually highlight the exploits of kings, aristocrats, and prelates.

In spite of the hard labor and preparations of Edward and his staff they were doomed to failure because his campaign was as ill-conceived as that of John and of Edward III between 1338 and 1340. Both John and Edward I confronted two of medieval France's ablest kings - Philip Augustus and Philip the

28 It should be noted that most of the principal officials of Edward such as those of the exchequer and wardrobe noted in this wardrobe book have been discussed by Tout in his Administrative History and in other studies. There are numerous references to these officials in the Calendar of Patent Rolls, 1292-1301. They are John de Dronkenesford (Droxford), keeper of the wardrobe; John de Benstede, controller of the wardrobe; Ralph de Manton, cofferer of the wardrobe; Walter de Beauchamp, seneschal of the household; and Walter Langton, treasurer of the exchequer and bishop of Coventry and Lichfield. 
Fair. In addition the leverage of the English kings over the export of wool to Flanders could not prevail over Flemish political divisions and tensions. Although such Flemish counts as Ferrand and Guy de Dampierre strived to preserve the political independence of Flanders, they were the vassals of the French kings which deprived them of political and military flexibility. And then there was always that strong faction of patrician leliaerts sympathetic to the French kings. In this uncertain and shifting political, social, and economic terrain these English expeditionary campaigns could not succeed. In the middle ages as in modern times a campaign, no matter how well organized and prepared, can but fail when poorly conceived. The end result is the wasting of economic and human resources and the unfortunate political consequences. 


\section{BRYCE AND MARY (†) LYON}

\section{Appendix}

Accounts of Richard de Wardington for Construction of Fosse Outside Ghent

\section{$\left(f^{\circ} 85 \mathrm{v}\right)$}

Compotus Ricardi de Wardington de operatione fossati extra Gandavum. (left margin) Ricardo de Wardington clerico deputato ad vadia operariorum operantium in fossato extra villam de Gandavo solvenda quod rex fieri precepit ad sumptus suos in primo adventu suo ibidem pro denariis per ipsum solutis Gerardo Merlebek magistro eiusdem fossati et 24 operariis operantibus in eodem fossato per unum diem videlicet xii diem Septembris predicto Gilberto [sic] per diem 6d. et cuilibet alii operario per diem 2 d., 5s. 4d. Et pro vadiis eiusdem Gerardi et Bartholomei de Gandavo magistrorum et 99 operariorum per xiii diem eiusdem mensis predicto Gerardo per diem 6d., Bartholomeo 4d. et cuilibet alii operario per diem 2d., 17s. 4d. Et pro vadiis eiusdem Gerardi percipienti per diem $6 \mathrm{~d}$. et trium vallettorum quolibet percipienti per diem $4 \mathrm{~d}$. et 199 operariorum quolibet percipienti per diem 2d. per xiiii diem Septembris 34 s. 8 d. Et pro vadiis 4 magistrorum quolibet percipienti per diem 6 d. et 218 operariorum quolibet percipienti per diem $2 \mathrm{~d}$. per $\mathrm{xv}$ diem eiusdem mensis 38s. 4d. Et pro vadiis eorundem magistrorum et 176 operariorum quolibet percipeinti per diem ut prius per xvi diem Septembris 31s. 4d. Et pro vadiis eorundem 4 magistrorum et 216 operariorum per xvii diem eiusdem mensis quolibet percipienti per diem ut prius 38s. Et pro vadiis eorundem 4 magistrorum et 209 operariorum percipientium ut prius per xviii diem eiusdem mensis 36s. 10d. Et pro vadiis eorundem magistrorum et 260 operariorum et 40 puerorum portantium hottas quolibet magistro percipienti per diem $6 \mathrm{~d}$., quolibet operario per diem $2 \mathrm{~d}$. et quolibet puero per diem 1d. per xix diem eiusdem mensis $48 \mathrm{~s} 8 \mathrm{~d}$. Et pro vadiis eorundem magistrorum et 360 operariorum per $\mathrm{xx}$ diem Septembris quolibet percipienti per diem ut prius $62 \mathrm{~s}$. Et pro vadiis eorundem magistrorum et 400 operariorum per xxi diem eiusdem mensis 68s. 8d. Et memoranda quod nullus operabat in eodem fossato xxii die Septembris propter solempnitacione diei Dominice. Et pro vadiis 4 magistrorum et 300 operariorum quolibet eorum percipienti per diem ut prius et 95 operariorum minorum quolibet percipienti per diem $11 / 2 \mathrm{~d}$. per xxiii diem Septembris 63s. 10 1/2d. Et pro vadiis eorundem 4 magistrorum et 306 operariorum per xxiiii diem Septembris 53s. Et pro vadiis eorundem 4 magistrorum et 309 operariorum per xxv diem Septembris 53s. 6d. Et pro vadiis 4 magistrorum quolibet percipienti per diem 4d. et 199 fossatorum quolibet percipienti per diem 2d. per xxvi diem Septembris 34s. 6d. Summa 29 lb. 6 1/2d. 


\section{THE LOGISTICS FOR EDWARD I'S ILL-FATED}

( ${ }^{\circ}$ 86r) Adhuc compotus Ricardi de Wardington. (left margin)

Eidem Ricardo de Wardington clerico pro vadiis 4 magistrorum et 300 fossatorum et 90 puerorum portantium hottas et operantium in eodem fossato pro vadiis suis per xxvii diem Septembris quolibet magistro percipienti per diem $4 \mathrm{~d}$., quolibet alio operario per diem $2 \mathrm{~d}$. et quolibet puero per diem $11 / 4 \mathrm{~d}$., 60 s. $81 / 2$ d. Et pro vadiis 2 magistrorum et 58 fossatorum per xxvii diem Septembris 10s. 4d. Et xxix diem Septembris non operabuntur pro festo diei Dominice. Et pro vadiis unius magistri, 60 fossatorum per ultimum diem Septembris 10 s. 4 d. Et pro vadiis 2 magistrorum et 28 fossatorum per primum diem Octobris quolibet magistro percipienti per diem 4d. et quolibet alio fossatoro per diem 2 d., $5 \mathrm{~s}$. 4 d. Summa $4 \mathrm{lb} .6 \mathrm{~s} .8$ 1/2d. Eidem pro signis plumbeis emptis per eundem ad liberandum operatoribus predictis ut per hec satisfacione posset eisdem. $21 / 2 \mathrm{~d}$.

Carpentarii. (left margin)

Eidem pro vadiis magistri Gerardi de Gandavo carpentarii et 21 carpentariorum operantium circa brestachiam faciendum ad dictum fossatum, predicto magistro 6d. et cuilibet alii carpentario per xvi diem Septembris 4d., 7s. 6d. Et pro vadiis dicti magistri Gerardi, 36 sociorum suorum carpentariorum per xvii diem Septembris $12 \mathrm{~s}$. 8d. Et pro vadiis 34 carpentariorum per xviii diem Septembris quolibet percipienti per diem $4 d$., 11 s. $4 d$. Et pro vadiis 4 carpentariorum per xix diem Septembris 16d. Et pro vadiis 5 carpentariorum per $\mathbf{x x}$ et xxi dies Septembris 3s. 4d. Et pro vadiis 3 carpentariorum per xxiii et xxiiii et xxv dies Septembris 3s. Et pro vadiis 4 carpentariorum per xxvi et xxviii, xxviii dies Septembris 4s. Et pro vadiis trium carpentariorum per ultimum diem Septembris et primum diem Octobris et nullus pro xxix die Septembris pro festo diei Dominice, cuilibet carpentario per diem $4 d$. ut prius $2 \mathrm{~s}$. Summa 45s. 2 d. 